\title{
Chain of Testimony: the Holocaust Researcher as Surrogate Witness
}

\author{
Anne Karpf \\ [Chapter for Nicholas Chare and Dominic Williams (eds.), Representing Auschwitz: At the Margins of \\ Testimony]
}

\section{Affect and Research}

On first learning that the Scrolls of Auschwitz, the testimony of the Sonderkommando found buried near the crematoria at Birkenau in the extermination camp itself, were to be analysed as literary documents, my reaction was an involuntary but resounding 'no'. Here, in its own way, was surely 'the surfeit of memory' that Charles Maier (1993) had talked about. Not only did it seem almost impossible to view the Scrolls as texts when their very materiality was so charged, but I also could not help but wonder how Nicholas Chare and Dominic Williams could mobilise their cognitive skills without also letting loose a school of other, less welcome, sensibilities. The Scrolls, I found myself initially thinking, belonged more in a reliquary than academic seminar. In the event (2010), Chare and Williams's meticulous scholarship and deep sensitivity rendered such misgivings redundant, and I dismissed my own first instincts as those of someone, a child of survivors, with a heightened engagement with testimony. Yet as I began to reflect more on the question, it seemed to me that such instinctual responses should not immediately be evicted but were themselves material that merited analysis because they touch on powerful ideas about how Holocaust research can and should be conducted, and speak of the existence of an underworld of unruly feelings that, by being exposed to the light of scrutiny and discussion, can help deepen and enrich Holocaust scholarship.

Debates about the role of affect in researching and writing about the Holocaust are not new: it is almost 15 years since Dominick LaCapra talked of the need 'to examine one's implication in the problems one studies issues that are pronounced with respect to extremely traumatic phenomena in which one's investment is 
great' (1998, p.17). Since then positivist assumptions and practices - that history can be studied dispassionately and objectively - have been so robustly challenged by postmodern critiques that it might seem as if the battle has been won and no self-respecting scholar could embark on Holocaust research with a sense of themselves as disinterested observer intact. And yet, in reality, Holocaust historiography remains dominated by a positivist historical method (Stone, 2012), and in practice it is common to find historical accounts where the idea that studying trauma might also produce it remains quite foreign. Historians rarely reflect on their own affective investment in the material they study; indeed, there is often an inverse relationship between the traumatic intensity of the event being studied and their readiness to discuss their own emotional involvement or the affective sources which led them to take up that research field in the first place. More than that, any leakage of feeling into research often still seems to be a source of shame, a transgression of the ideal type researcher. What appears to be demanded of the historian, in such cases, is the blank canvas of the psychoanalyst, upon which history itself can project its own feelings. This kind of history has its roots, according to Hayden White, in the 'profound hostility to all forms of myth' (White, 1978, p.123) in historiography after the French Revolution, which required the historian to expunge from their apprehension of reality any intuitive processes.

In reality, of course, analysts themselves have feelings, and those treating Holocaust survivors have described the anxieties stirred up in them when they have encountered the horrors of the concentration camps experienced by their patients. In such cases the psychoanalyst has to confront their own resistances in order to help produce an effective analysis. Ilse Grubrich-Simitis has argued that 'The ability to empathise with sufferers is a precarious cultural acquisition' (Grubrich-Simitis, 1981, p.442), and is threatened by the defences activated by the analyst to protect themselves against the revival of the infant's feeling of extreme helplessness in the face of existential threat. By identifying with the survivor patient 'are we not in fact afraid that...we might experience, albeit in an incomparably weaker form, something of that which the survivors actually lived through?' (p.444) In order to be able to help the analysand the analyst has to achieve their own 'successful' work of mourning the Holocaust (Grubrich-Simitis, 1984).

Historians are not psychoanalysts, yet neither can historical method seal them against the transference and counter-transference set off by Holocaust research. Researchers, no less than psychoanalysts, experience resistances and defences of their own in working with traumatic material. Dealing with testimony, LaCapra 
argues, 'raises the issue of the way in which the historian or other analyst becomes a secondary witness, undergoes a transferential relation, and must work out an acceptable subject-position with respect to the witness and his or her testimony' (1998, p.11). The refusal of some historians to engage with testimonial literature, according to Federico Finchelstein, 'is also a mechanism of defense, of neutralizing one's own subject-position vis-a-vis the traumatic charge that seems to emanate from victims' testimonies' (Laub and Finchelstein, 2010, p.59). The role of secondary witness places a heavy burden of responsibility on the researcher, and positions them in a relay of memory - a chain of testimony in which they act as a medium for the transmission of first-hand accounts to future generations for whom the Holocaust will be nothing but history. In the case of testimony left by victims rather than survivors, the burden is even heavier, and the researcher becomes not only a secondary witness but in some sense also a surrogate one, charged with speaking on behalf of those who no longer can.

One might argue that this is the case with historical documents of any kind - preserving and transmitting 'thick' description and memory left by preceding generations is the very nature of the historical task - and yet when the testimony concerns such a comprehensive and unprecedented attempt to extirpate memory itself, its retrieval enlists the researcher (albeit in footling fashion) in the project to challenge both Nazi ideology and the whole National Socialist enterprise. Rare must be the researcher in whom an alternating sense of impotence and omnipotence, inadequacy and awe are entirely absent. These sentiments, I want to suggest, are legitimate material for debate and discussion, and not extrinsic to the historical events themselves. We are tempted, perhaps, to write them off because, in the crude Freudianism that is current and widespread, psychic responses are thought to result almost entirely from individual subjectivity: they reside in the personal unconscious and appear autonomous. Although cultural studies have been deeply informed by psychoanalysis, bringing psychoanalytic theories into contact with Holocaust research (or, even worse, the Holocaust researcher) still seems to represent a dangerous turn away from historical and sociological analysis, running the risk of banalising the Holocaust and narcissistically replacing the perpetrators, victims and bystanders as the focal point of research with the researchers themselves.

In reality, 'structures of feeling' (Williams, 1986) are as culturally produced and historically contingent as the notion that you can do history without feeling, and our affective responses to the encounter with Holocaust material are themselves a historical resource. By keeping these emotions latent we not only deny ourselves 
another dimension through which to understand the Holocaust and its aftermath but also endow them with the power to destabilise the research. It must be stressed that we are engaged here in a project not of psychohistory (which often hovers intolerably close to exculpation) or any kind of speculative psychological profiling of either perpetrators or victims but rather the adopting of a reflexive stance about the researcher's own practice:

'Without at least the awareness of what defence mechanisms are and what they do, the historian is at the mercy of her own repressions. These repressions and resistances will determine, to a certain extent, what it is the historian chooses to write about or not write about. What gets excluded from history, then, has as much to do with what it is historians can psychically handle' (Morris, 2001, pp.54-55).

Dirk Rupnow has argued, for example, that historians have been reluctant to describe in detail what happened in the gas chambers in part through self-protection and their inability to bear those details (Rupnow, 2012). On the other hand the blithe confidence of Hugh Trevor-Roper, author of 'The Last Days of Hitler', when he wrongly authenticated the forged diaries of Hitler, may have owed something to a sense of grandiosity developed when studying Hitler's final months in the bunker (Rosenbaum, 1998).

My concern here is with what gets excluded from history but also with the psychological freight that history has to carry. My starting-point is my own psychic load as the daughter of Holocaust survivors. I have described elsewhere (Karpf, 2008) my experiences growing up with survivor parents, and the dawning realisation that much of what I'd assumed to be a purely personal pathology was actually common to members of the socalled 'second generation'1 ${ }^{1}$. Since the book's original publication in 1996, the circles of impact have widened further still, and I have become aware that some of the reactions that I had assumed were confined to children of survivors are, in fact, shared by those without direct personal connections to the Holocaust: they are part of what Marianne Hirsch calls 'postmemory'. Although Hirsch coined this phrase to describe children of Holocaust survivors and of parents who had suffered other collective traumatic experiences, it seems to me to bear application more generally also to those born after the Holocaust and grappling with it in various ways, since she defines postmemory as 'a powerful and particular form of memory precisely because its connection to its object or source is mediated not through recollection but through an imaginative investment and creation' (Hirsch, 1997, p.22). 


\section{Impulses and phantasies}

Freud identified the rescue phantasies that some men have for women (1958a). Children of Holocaust survivors, overwhelmed by the stories they have heard or gleaned about their parents' experience of extreme brutality and the prospect of annihilation, commonly entertain retrospective rescue phantasies of their own. I want to suggest that Holocaust researchers and commentators, while they remain sufficiently in touch with reality to know that the victims of Nazism remain dead, and that pivotal events that helped survivors to survive took place decades earlier, may have their own version of the rescue phantasy, but in this they help rescue the survivor, or, more poignantly, the victim, not from death but from oblivion. They are tasked with pulling memory from the rubble of the past, of reviving memories and descriptions that have been almost obliterated, to claim a place for victims and survivors in collective memory. In the case of the Scrolls of Auschwitz how much more compelling might rescue phantasies be since the testimony literally had a humus of crematoria ashes and decomposed bone clinging to it. How hard it must have been, one imagines, for Chare and Williams, and the Scrolls researchers who preceded them, to resist the idea that these artefacts represented an unmediated past, a synecdoche, a frayed remnant of the Holocaust itself. Or to eschew the phantasy that in some way they might be imaginatively resuscitating its authors...

Claude Lanzmann has made explicit his own rescue phantasies, as expressed in his film 'Shoah', where he fixates on the loneliness of the death of Holocaust victims, and retrospectively inserts himself into their narrative to keep them company:

'The idea that always has been most painful for me is that all these people died alone... A meaning for me that is simultaneously the most profound and the most incomprehensible in the film is in a certain way... to resuscitate these people, to kill them a second time, with me accompanying them' (Qtd in LaCapra, 1998,p.133)

Interestingly, even in phantasy Lanzmann cannot entertain such omnipotence as could reverse time (for some, this may be the only way of engaging with the Holocaust; it was given fictional form in Martin Amis's novel 'Time's Arrow', 1992), although the impulse to somehow defeat or overcome time is certainly a common response to the Holocaust. In 'The War After' I described how tenaciously in my imagination I had clung to an 
old and mythologised Poland until I actually visited the country. Even then I viewed the present through the lens of the past, imbuing each receipt and postcard with a sense of 'lostness' far in excess of what it might actually sustain, 'as if they were archaeological relics encoded with meanings and potential clues' (p.297). After visiting both Plaszow and Birkenau, where my mother was an inmate, I came to realise how thoroughly I had

confused time and place, history and geography, as if coming in person to the site of terrible events which occurred fifty years ago could somehow yield them up for us to transform them - they might actually extrude through the stones and the earth and be mitigated by modern sorrow. But it is time which has enfolded and buried those events, not place, and it was their contemporaries on different continents who had the possibility of intervening, not those of us standing here now. (p.300)

This attempt to erase the distance between past and present is not, I've come to believe, particular to children of survivors, even though we may experience it particularly acutely, but embeds itself in the undertow of much historical research and cultural debate. Implicit in the project of recording is the impulse to prevent the kind of 'second murder' committed by time itself: time becomes not just the agent of forgetting but an active accomplice in the task. Research and writing, by contrast, act as an antidote, a countervailing force, seeming to confer immortality. Pierre Nora has argued that our 'hallucinations of the past', the result of discontinuities and distance from events, stoke our sense of wanting to retrieve the past's secrets. 'The most fundamental purpose of the lieu de memoire is to stop time, to block the work of forgetting, to establish a state of things, to immortalize death, to materialize the immaterial... to capture a maximum of meaning in the fewest of signs' (1989), even though, as James Young has pointed out, 'once we assign monumental form to memory, we have to some degree divested ourselves of the obligation to remember' (Young, 1993).

Lanzmann has acknowledged how the recurring desolate images of rolling trains in 'Shoah' expressed a yearning for the erasure of time:

These disfigured places are what I call nonplaces of memory (non-lieux de memoire). At the same it is nevertheless necessary that traces remain. I must hallucinate and think that nothing has changed. I was conscious of change but, at the same time, I had to think that time had not accomplished its work. (Qtd in LaCapra, 1998, p.133) 
We must guard against pathologising such phantasies but rather recognise them as one way of dealing with trauma and the painful feelings of impotence that it can excite in the secondary or surrogate witness. Another way of dealing with such secondary trauma is through what LaCapra calls 'archival fetishism'. The anguished exhortation of the historian Simon Dubnow, murdered by the Nazis, 'Shreibt un farshreibt!' ('Write and record!') (Marrus, 1997, p.xiii), seems to have been infused with almost magical properties, so fiercely and religiously have researchers adhered to it, recording whatever minutiae of life and death under Nazism can be recovered. It sometimes seems as though every receipt or timetable, each log or inventory, has evidentiary potential, as if, with sufficient determination and graft on the part of the researcher, some new constellation of information might be revealed.

It is impossible not to be moved by the scrupulousness of much of this research and its pressing agenda of recovery. In part it is a belated response to survivors' need to bear witness and be listened to, a need mostly unmet in the aftermath of the war and for years to come. Primo Levi found that speaking and not being listened was almost as grievous to him as his camp experiences, and represented a second abandonment by the world after the first abandonment during the war (Levi, 1987, p.227).

And yet, on occasion, when it comes to documentation, there is an almost palpable excess in operation, and the boundary between a thing and a person, a document and the individuals who produced it, is at risk of becoming dissolved, or at least made tenuous. Even Raul Hilberg, the archetypal 'rational' historian, found himself in thrall to the magical aura of some of his sources. In 'Shoah', he hinted as much when he tried to explain to Lanzmann why documents were so fascinating to him:

Well, you see, when I hold a document in my hand, particularly if it's an original document, then I hold something which is actually something that the original bureaucrat held in his hand. It's an artifact. It's a leftover. It's the only leftover there is. The dead are not around. (Qtd in LaCapra, 1998, p.132)

The care extended to Holocaust documents is all the more poignant because these are traces, leftovers, remnants (Agamben, 2008). Each time we handle attentively a Holocaust testimony or the records of a victim, it brings into consciousness, or to its rim, the lacunae that cannot be filled, the documents that will not be found and, most unspeakably, our knowledge of the lack of care and humanity allowed to its subject. Or as Helga Satzinger put it, 'So much effort put into preserving records of people, and so much effort put into their 
murder. ${ }^{2}$ Testimony is always in dialogue with silence and absence; the more heedfully and thoughtfully we treat it, the more painful it becomes.

\section{Traces}

Phantasies of comprehensiveness and completeness dog most archival researchers at one time or another, whatever their field, yet in the case of Holocaust research these are particularly charged, because of the Nazis' declared intention to remove all traces of their crimes, and produce a genocide without witnesses or traces, leading to claims of 'memorycide'. Thus behind archival fetishism lies an even larger project, one in which remembering and retrieving are endowed with almost prophylactic capacities, and the potential to somehow avoid a recurrence of atrocity, if only every shred of evidence is exhumed and preserved. As Rupnow has argued, "Destruction and forgetting on the one hand and remembrance and justice on the other hand are usually seen as not simply arbitrarily linked but as inseparable in their character" (Rupnow, 2012, p.63)..$^{3}$ It is as though historical memory carries some sort of retributory charge, and the very act of memorialising is not only a retrospective act of preservation but also, somehow, a prospective one too - a reversal of time's arrow indeed.

For the Jewish researcher in particular, recovering traces and witnesses can thus become a small but significant act of retrospective resistance, which can all too easily slide into a compulsion. The case of Edmund de Waal is one such example. In The Hare With Amber Eyes, his fine account of how he tracked, through the biography of the netsuke bequeathed him by his great uncle, his ancestral Jewish family's experiences in Europe under Nazism, de Waal relates how he tries 'to hunt down' every picture that hung in his ancestor Charles Ephrussi's room in 19th century Paris. He starts to list all the museums in which the paintings now hang, to trace how they got there, and contemplates how long it would take him to go to them all, to see 'if I can see what his eyes saw' (2007, p.87), before he realises the impossibility of the task. But the impulse is there, and de Waal's obsession with the tiniest detail of his ancestors' lives, his copious chronicling of the provenance, placing and afterlife of their artefacts, gives the measure of his grief. 
The compulsion to chronicle copiously is a reparative one: it tries to re-humanise those who were dehumanised in the Holocaust. Perhaps, too, it acts as a_kind of obsession-compulsion that helps to keep at bay the horror. If one is always engaged in research one never has time to stop and let the subject matter overwhelm one. As Griselda Pollock, writing about Charlotte Salomon's 'Leben? oder Theater?', put it:

What is a subject in catastrophic circumstances when all that "I" appear to be under is the condition of subjective dissolution and politically encompassed annihilation? Charlotte Salomon used love and philosophy. They did not save her. But she has a name. We must honor it by reading her work with care. (Pollock, 2011, p.14)

De Waal observes, of his own obsessive chronicling, 'I think... of all the listings of families in the manifests, for deportations. If others can be so careful over things that are so important, then I must be careful over these objects and their stories' (p.348).

Maike Rotzoll, a German psychiatrist, has researched the murder of institutionalised German psychiatric patients at six killing centres under the Aktion T4 euthanasia programme. Together with colleagues, she used the discarded files of 3000 of these patients, found after the fall of the Berlin Wall, to discover on what basis they were selected for the gas chambers. Most of these patients have, until now, had no name. Indeed, until recently there was little interest in them: although there was a card index of perpetrators, none existed of victims. At the very least Rotzoll and her colleagues are trying to rescue them from anonymity and name them; where possible they have also attempted to reconstruct their life stories. Patients such as Karl Ahrendt, killed at 87,33 years after he was first hospitalised: 'After his admission', Rotzoll notes, 'Ahrendt didn't exist any more - he vanished behind official forms' (2010). The treasure trove of paintings by the incarcerated that they also found, such as drawings by Wilhelm Werner, 1898-1940, a victim of compulsory sterilisation, reveal the human subjectivity behind the number. His work is among that exhibited at the Prinzhorn Cellection Museum in Heidelberg. ${ }^{4}$

As Baudrillard put it, 'Forgetting extermination is part of extermination, because it is also the extermination of memory, of history, or the social' (1994). ${ }^{5}$ Naming thus becomes important not just as a historical tool but also as an act of memorialising. The gathering of names takes on the flavour of a commemorative book; it is a small gesture of Wiedergutmachung. Perhaps because of the nature of the material, and also because she is a 
German psychiatrist working on files in which her predecessors are implicated, Rotzoll is sensitive to her own investment in the project. 'We're psychiatrists and seeing every day patients who would have been murdered under the Nazis. Reading a file you seem to be in contact in some way with that person. The most difficult moment is to put the file away: you don't know if, in the future, anyone will ever look at it again. ${ }^{6}$ Like Lanzmann, Rotzoll has tried to 'accompany' her subjects, but has had to painfully acknowledge the moment that they part.

\section{Sacralisation}

The suggestion that Holocaust researchers and writers should scrutinise their own engagement with trauma might be thought to bring risks of its own, most notably that, in rejecting a positivist methodology, we embrace an over-identification with the victim, something of which LaCapra rightly accuses Lanzmann (1998). In Lanzmann's case he went so far as to publicly humiliate an Auschwitz survivor who planned to screen a documentary with which he disagreed, and to excoriate anyone who attempted to seek explanations as to why the Holocaust took place. In appropriating the terrible dictum of an SS guard to Primo Levi - 'Hier ist kein warum' (here there is no why) - and perversely recasting it as his own slogan, Lanzmann loses not only any sense of humility but also hubristically marks out the acceptable field of study in his capacity as surrogate survivor-in-chief (Rosenbaum, 1998).

Self-aggrandisement is not particular to Lanzmann. Daniel Goldhagen, author of 'Hitler's Willing Executioners', claimed to be 'reconceiving central aspects of the Holocaust' (1997, p.3). He deliberately 'eschews the clinical approach' in his account of 'blood, bones and brains flying about' (p.22). Though his emotional description of the killing of little girls by members of the Einsatzgruppen, according to LaCapra, veers perilously close to kitsch (2001), Goldhagen, whose father was a refugee from Europe, was highly resistant to attempts to explore the origins of his approach to the Holocaust, and regarded allegations of 'displaced, unacknowledged revenge impulse' as intrusive (Rosenbaum, 1998). Yet in trying to avoid objectifying the victims, Goldhagen might be said, like Lanzmann, to have over-identified with them. (Shalom Auslander's comic novel, Hope: a Tragedy, briliantly satirises through the character of the hero's grandmother this impulse of post-Holocaust generations to insert themselves retrospectively into the narrative (Picador, 2012).) In reality the researcher or critic is 
more, and not less, likely to produce a sentimentalised, sacralised representation of the survivor or victim if they fail to be attentive to their own projections. Let me give you a cautionary tale from my own experience.

In January 1998 The Guardian sent me to interview Binjamin Wilkomirski, author of the already acclaimed supposed Holocaust memoir 'Fragments' (1996). I was moved by both book and author, despite two fleeting concerns. (It is hard to recover these on exactly the scale that they struck me at the time, so tempting is it to place oneself retrospectively in the 'doubters' camp, but I shall try.) Firstly, Wilkomirski told me that he didn't know how old he was but that 'my doctors guess that I might have been born at the end of 1938 or the beginning of 1939' (Karpf, 1998, pp.2-3). In the interview, though, he also mentioned that January 22 was his birthday. I phoned him later to ask him to clear up the contradiction, and he elaborated that he celebrated January 22 as his birthday because this was the date that he emerged from Birkenau. Consequently I started my article with the sentence, 'It was only after I'd left Binjamin Wilkomirski in his hotel room that it occurred to me that he was a man without a birthday, ' and then went on to talk about the substitute birthday that he'd fashioned for himself. In other words I did some of the interpretive work on Wilkomirski's account in order to resolve the contradiction: I placed the two comments together in a mutually supportive sequence.

Secondly, I was struck by how lachrymose Wilkomirski was. I grew up in a community of survivors and hardly ever saw one cry: most of them had learnt to armour themselves against tears during the Holocaust and those I knew well were at the steely end of the emotional spectrum. Wilkomirski's tears flickered somewhere on my gauge of discrepancy but I never pursued this. Moreover, when I recounted the contents of both book and interview to my mother, she immediately retorted that there were no child survivors of Majdanek, and certainly not one so young. I dismissed her reaction. What is intriguing in hindsight is that I was more able and willing to discredit my mother's response than I was able to discount Wilkomirski's. Why did I - admittedly, not alone - prove so gullible, especially since Lawrence Langer, among many others, has protested that, from his first reading, he 'assumed that Fragments was a fictional narrative'? (2006, p.50)

One's reading of any text is shaped by many factors: in this case, mine could be said to have been overdetermined. The book arrived already lionised as a memoir, which seemed a guarantor of its facticity. Its very fragmentariness seemed to mimic the broken nature of memory and in particular a child's memory, lending it further authenticity. It was the Holocaust story, perhaps, that was yearned for as the century in 
which the Holocaust took place was drawing to a close - the story of the child who survived what Anne Frank did not, who could take the 'late born' into the next century, and the perfect 'postmodern ' text, fragmentary, without strict chronology. But there were also personal reasons that predisposed me to believe Wilkomirski and allow my reservations only whispering room. My reactions were shaped primarily, I now think, by my relationship with Holocaust testimony, specifically that of my mother, which had occupied a central, incontestable place in my life. While I could challenge my mother's reaction to Wilkomirski's book - that, after all, was simply her opinion, albeit a highly informed one - I could no sooner dispute his apparent testimony than that of my own parents. My own excess became clear in my feelings when his duplicity was unmasked: a deep sense of rage at the deception, at his appropriation of a story that was more 'mine' than 'his' (in reality, it belonged to neither of us) and at the exploitation of my own readiness to believe that had been forged so painfully in my childhood.

\section{Fractures}

Most survivor families are highly sensitive to the rupture of the family line, and find different ways of trying to come to terms with it, but the recognition of and response to the fragmentation of the subject (which Wilkomirski so unerringly identified in the title of his work) is a key issue in Holocaust narrative generally. While Freud compared the joint work of analyst and patient to an archaeologist's excavation of a destroyed or buried building (1958d), Foucault stressed the discontinuities and fractures, thresholds and limits present in historical analysis: he argued for the questioning of 'ready-made syntheses', and their replacement by the idea of 'dispersed events' (1989, p.24). Nevertheless, Dori Laub claims, the Holocaust researcher can synthesise the traumatic testimony of survivors into a unified narrative: 'the historian is now in a position to witness those fragments that have come together and to integrate them with facts that she has from other sources (Laub and Finchelstein, 2010, p.57). Yet surely the researcher must resist the temptation to reconstitute the shards of testimony into something too whole: unbroken is an adjective, describing a pristine state - there is no verb

to 'unbreak'. (This should not be confused with the argument that the Holocaust is essentially unrepresentable and incomprehensible - an argument that Rupnow (2012) expertly dismantles.) Indeed the Scrolls of Auschwitz, as described by Chare and Williams, are themselves material metaphors of Holocaust memory buried, uncovered, recovered, restored but always fragmentary. It seems fitting that they were discovered in different decades - the 1940s, 50s, 60s and 80s, like different sedimentary layers of memory and 
understanding, a palimpsest, a reminder that retrieval of Holocaust evidence can never be complete, and will always inevitably be refracted through the time of its finding. Chare, in his understanding of the problematics of restoration and the risks of normalising the Scrolls, seems exquisitely able to tolerate their brokenness (2011)

Chare and Williams have also acknowledged what so many researchers have found unbearable: the enforced complicity of the Scrolls' authors - members of the Sonderkommando and thus of what Primo Levi called 'the Grey Zone' (1989) - in mass murder. As a result, following James Young (1988), they can summon the cool historicity to view the Scrolls as literary documents, and are able to wrest deeper, more extraordinary meanings from them: that the penmanship of one of the Scrolls' authors, Leyb Langfus, suggests 'that he saw himself as a self. This is not the writing towards disintegration' (Chare, 2011, p.85); that even in such close proximity to the crematoria, precision of expression was so highly valued. This helps us understand that, in such conditions, precision of expression becomes not a creative flourish or literary self-indulgence but an existential imperative.

Chare sets himself against 'a perceived quasi-spiritual revelation of the truth of the object', in favour of a deep theoretical engagement with the Scrolls and their materiality, and argues that they demonstrate 'a faith in the testimonial capacity of language under the most extreme conditions' (pp.xx-xxi). Yet this is no easy, redemptive uplift, of the kind that takes place at the end of 'Schindler's List', where the survival of a handful of Jews seems to have begotten an entire nation, seemingly a replacement for those who have died. Or the sort of redemption found all too often in writings about Anne Frank, whose ruthlessly decontextualised few lines about still believing that people are good at heart that have become so famous (the ones about people's innate "urge to destroy.. to kill.. murder and rage" have curiously never found equal fame) have turned her into an emblem of forgiveness, as though she were in some sense anticipating her own death and absurdly exonerating those responsible. Even as generally sensitive a critic as Francine Prose colludes with this trope, arguing that Anne Frank lives on in the vitality of her writing, just as she always wanted to (2010). But Anne Frank isn't alive: she died a horrible death (Karpf, 2010). Gabriel Josipovici has argued that 'when communal memory, dialogic memory, breaks down or disappears, myth rushes in to fill the gap' (Josipovici, 1999, p.323). Little exemplifies this more than the mythologising of Anne Frank. 
So how can the Holocaust researcher steer a path between a positivist refusal to reflect on their own implication in what they study, and an over-identification with the victim that produces such intolerable anxiety that they must vaporise it with consoling messages or the illusion of having reunited the shards of testimony? Saul Friedländer suggests that 'the voice of the commentator' should be clearly heard, and it should 'disrupt the facile linear progression of the narration, introduce alternative questions' (qtd in Eaglestone, 2004, p.187) but 'without giving in to the temptation of closure' (1994, p.261). LaCapra calls for 'empathic unsettlement' (2001, p.41), a receptivity to other people's traumatic experiences without their appropriation, and the undergoing by the historian of 'muted trauma' (1998, p.40).

Both Friedländer and LaCapra's proposed stance are variants of what Freud called 'working through', rather than 'acting-out'. In the latter, the patient repeats in the form of an action a trauma that they have repressed repeats instead of remembering. In working through, by contrast, the patient attains a reconciliation with their repressed material through the medium of the transference, which allows it to change (Freud, 1958b). Similarly while mourning results in the patient's eventual return to vitality, its pathological form, melancholia, involves a narcissistic identification with a lost object (Freud, 1958c). Indeed we could see archival fetishism as a refusal to mourn the lost object: by choosing instead a melancholic attempt to preserve it, this kind of research paradoxically keeps it lost. Working through and mourning are related to what Melanie Klein called the 'depressive position', in which the persecutory anxieties to be found in the split paranoid-schizoid condition become more muted as the infant learns to tolerate ambivalence, and reaches the stage where the internal object can be simultaneously loved and hated Klein, 1986). For Holocaust scholars and commentators, the depressive position can serve as a foil to omnipotent phantasies, an encouragement to accept those limitations that the 'completism' of archival fetishism denies. Hannah Arendt, though she was famously hostile to psychoanalysis, adopted a stance not dissimilar to the depressive position when she maintained that, as regards the Holocaust, 'the best that can be achieved is to know precisely what it was, and to endure this knowledge, and then to wait and see what comes of this knowing and enduring' $(1993$, p.20).

The Hare With Amber Eyes exemplifies the work of mourning and a hard-won attainment of the depressive position. The book ends with de Waal's journey with his younger brother, Thomas, to Odessa, the city where the Ephrussi family started. They find the family house only to learn that it has just been renovated, its remaining original contents despoiled and discarded only a month before. 'I am too late', de Waal laments, his 
mania for chronicling artefacts finally left unsatisfied. But as he looks out of the window at the vista to the Black Sea he realises that traces of his ancestors are still, in some sense, there, in the stories of Isaac Babel and in the charitable endowments they left behind. This understanding seems to free him to 'Let it go. Let it lie. Stop looking and stop picking things up... Just go home and let these stories be' (2010, p.346). De Waal's compulsion to document, though it results in an eloquent book, trapped him in a quest for infinite detail, one carrying a powerful emotional charge and libidinal energy. It is only once he works out what has been killed off and what remains - an essential task of mourning - that he is able to let go and allow the past to be past.

On the other hand, we could argue that the task of integrating the Holocaust into Jewish life and history without melancholia is too psychically and culturally great to be achieved either individually or - so relatively soon after the events themselves - historiographically. Perhaps the depressive position is only occasionally attainable. Josipovici counsels that 'We must accept that we cannot respond as we ideally should, and that sometimes we cannot respond at all. We should ask ourselves how often our involvement with the details of the Holocaust has more to do with our own pathology, with our suppressed guilt and our suppressed masochism' (pp.326-7).

The case of the historian Otto Dov Kulka demonstrates both the limitations of history from which all affect has been evicted, and the impossibility of achieving a neat synthesis of documentation and reflexivity. Kulka's example is an extreme one, in that he is both a historian and a child survivor. Now based in Jerusalem, he was born in 1933 in Czechoslovakia, from where, aged 10, he was deported with his mother first to Theresienstad and thence to the 'family camp' in Auschwitz. Kulka had, as a historian, described this camp and its liquidation in an article based on documents he had found in German archives, an article in which 'I use the third person, as one who is describing a distant historical reality' (Kulka, 2013, p.18). Indeed, he assumes that:

readers of my historical publications will have identified me unequivocally with an attitude of strict and impersonally remote research, always conducted within well-defined historical categories, as a kind of selfcontained method unto itself. But few are aware of the existence within me of a dimension of silence, of a choice I made to sever the biographical from the historical past. (p.xi)

Eventually, however, this professional exile from his biographical past became unsustainable: 
That rigorous 'pure scientific' writing is fraught with tremendous 'meta-dimensional' baggage and tensions... The fact is that in all my research I never had to deal with the stage, the dimension, of the violent end, the murder, the humiliation and the torture of those human beings. I left, or skirted that dimension.(pp.82-3)

In a slim new volume he faces it directly. Saturated with affect and a recovered subjectivity, alongside dreams and speculation, his memoir ends with a near-disintegration of the rational, which is replaced by an almost messianic, quasi-religious vision. An appendix reprints his article on the family camp, from which Kulka qua inmate is banished. The contrast is astonishing - a colossal psychic split made manifest within the covers of a brief book. Kulka, even now, understands only too well the rationale for his former stance: 'had I not found that 'safe passage' I could not have borne those tensions and anxieties' (p.93).

While most contemporary Holocaust researchers and commentators do not have to carry the 'metadimensional' baggage that Kulka does, developing an understanding of the routes that they have taken to ensure their own 'safe passage' can only enhance their work.

I am grateful to Dan Stone and Daniel Pick for their invaluable comments on this paper.

\footnotetext{
${ }^{1}$ A term I dislike precisely because it places children of survivors in too close a relationship with their parents' experiences, presuming an identification which it should be problematising

${ }^{2}$ Personal communication, 21.10.11

${ }^{3}$ Rupnow, op cit, p63. Rupnow has challenged the concept of 'memorycide', arguing that, in reality, the Nazi politics of memory was much more ambivalent and contradictory, and amounted to an attempt to 'Aryanise' the representation of their crimes.

${ }^{4}$ See also Die Namen der Nummern (berlin: Fischer, 2007), in which Hans-Joachim Lang identifies the 86 victims gassed by the Nazis in August 1943 in Natzweiler-Struthof concentration camp.

${ }^{5}$ This is also the title of a book by Rotzoll and her colleagues (Fuchs et al, 2007)

${ }^{6}$ Personal communication, 21.10.11
}

\section{Works Cited}

Agamben, G. (2008) Remnants of Auschwitz, trans. D. Heller-Roazen (New York: Zone Books).

Amis, M. (1992) Time’s Arrow (London: Penguin).

Auslander, S. (2012) Hope: a Tragedy (LOndon: Picador) 
Arendt, H. (1993) Men in Dark Times (Orlando: Harcourt Brace).

Baudrillard, J. (1994) Simulacra and Simulations - III. Holocaust, trans. S. Glaser, [online] Available at: <http://www.egs.edu/faculty/jean-baudrillard/articles/simulacra-and-simulations-iiiholocaust/> [Accessed 6 August 2012].

Chare, N. (2011) Auschwitz and Afterimages (London: I. B. Tauris).

Chare, N., and Williams, D. (2010) ‘The Scrolls of Auschwitz: Visual and Literary Analyses', paper for workshop Witnesses to the Holocaust: The Scrolls of Auschwitz and the Matter of Testimony, University of Reading, 26 March 2010.

Felstiner, J. (1995) Paul Celan: Poet, Survivor, Jew (New Haven: Yale University Press, 1995).

Eaglestone, R. (2004) The Holocaust and the Postmodern (Oxford: Oxford University Press).

Foucault, M. (1989) The Archaeology of Knowledge (London: Routledge).

Freud, S. (1958a) ‘A Special Type of Choice of Object Made by Men', in The Standard Edition of the Complete Psychological Works of Sigmund Freud, trans. James Strachey (London: Hogarth Press), vol. xi.

Freud, S. (1958b) ‘Remembering, Repeating and Working Through', Standard Edition, vol. xii.

Freud, S. (1958c) Mourning and Melancholia', Standard Edition, vol. xiv.

Freud, S. (1958d) 'Constructions in Analysis', Standard Edition, vol. xxiii.

Friedländer, S. (1994) 'Trauma, Memory, and Transference', in G. Hartman (ed.) Holocaust Remembrance (Oxford: Blackwell).

Fuchs, P., et al. (2007) Das Vergessen der Vernichtung ist ein Teil der Vernichtung selbst: Lebensgeschichten von Opfern der nationalsozialistischen "Euthanasie" (Goettingen: Wallstein Verlag).

Grubrich-Simitis, I. (1981) ‘Extreme Traumatization as a Cumulative Trauma: Psychoanalytic Investigations of the Effects of Concentration Camp Experiences on Survivors and Their Children', Psychoanalytic Study of the Child, 36, 415-50. 
Grubrich-Simitis, I. (1984) 'From Concretism to Metaphor: Thoughts on Some Theoretical and Technical Aspects of the Psychoanalytic Work with Children of Holocaust Survivors', Psychoanalytic Study of the Child, 39, 301-319.

Hirsch, M. (1997) Family Frames: Photography, Narrative, and Postmemory, (Cambridge, MA: Harvard University Press).

Josipovici, G. (1999) 'Memory: Too Much/Too Little', in E. Timms \& A. Hammel (eds.) The German/Jewish Dilemma: From the Enlightenment to the Shoah (Lampeter: Edwin Mellen Press), pp. 317-327.

Karpf, A. (1998) 'Child of the Shoah', The Guardian, 11 February, 2-3.

Karpf, A. (2008) The War After: Living With The Holocaust (London: Faber).

Karpf, A. (2010) Review of F. Prose, Anne Frank: The Book, the Life, the Afterlife, The Guardian, 21 August, [online] Available at < http://www.guardian.co.uk/books/2010/aug/21/anne-frankfrancine-prose> [accessed 3 December 2012].

Klein, M. (1986) 'A Contribution to the Psychogenesis of Manic-Depressive States', in J. Mitchell, ed., The Selected Melanie Klein (London: Penguin).

Kulka, O. (2013) Landscapes of the Metropolis of Death (London: Allen Lane).

LaCapra, D. (1998) History and Memory After Auschwitz, (Ithaca: Cornell University Press).

LaCapra, D. (2001) Writing History, Writing Trauma (Baltimore: The Johns Hopkins University Press).

Langer, L. (2006) Using and Abusing the Holocaust, (Bloomington: Indiana University Press).

Laub, D., and Finchelstein, F. (2010) 'Memory and History from Past to Future', in Y. Gutman et al. (eds.) Memory and the Future (London, Palgrave Macmillan), pp. 50-65.

Levi, P. (1989) The Drowned and the Saved, trans. R. Rosenthal (London: Abacus).

Levi, P. (1987) If This is a Man and The Truce, trans. S. Woolf (London: Abacus).

Maier, C. (1993) 'A Surfeit of Memory? Reflections on History, Melancholy and Denial', History and Memory, 5:2 (Fall-Winter), 136-153.

Marrus, M. (1987) The Holocaust in History (London: Penguin). 
Morris, M. (2001) Curriculum and the Holocaust: Competing Sites of Memory and Representation (Mahwah, NJ: Lawrence Erlbaum Associates, 2001).

Nora, P. (1989) 'Between Memory and History: Les Lieux de Mémoire’, Representations, 26 Special Issue: Memory and Counter-Memory (Spring), 7-24.

Pollock, G. (2011) Allo-Thanatography or Allo-Auto-Biography: A Few Thoughts on One Painting in Charlotte Salomon's 'Leben? oder Theater?', 1941/42 (Ostfildern: Hatje Cantz).

Prose, F. (2010) Anne Frank: The Book, the Life, the Afterlife (London: Atlantic Books).

Rosenbaum, R. (1998) Explaining Hitler (London: Macmillan, 1998)

Rotzoll, M. (2011) 'The Nazi Patient killing “Aktion T4”', paper given at 'Science, Medicine and the Holocaust: Recent Research and Memorial Practices in Germany', Wiener Library, 21 October.

Rupnow, Dirk. (2012) 'The Invisible Crime: Nazi Politics of Memory and Postwar Representation of Books). the Holocaust' in Stone.D. The Holocaust and Historical Methodology (Oxford: Berghahn

Stone, D. (2012) Introduction, The Holocaust and Historical Methodology (Oxford: Berghahn Books).

de Waal, E. (2007) The Hare With Amber Eyes (London: Vintage).

White, H. (1978) Tropics of Discourse: Essays in Cultural Criticism (Baltimore: The Johns Hopkins University Press).

Wilkomirski, B. (1996) Fragments (London: Picador).

Williams, R. (1986) The Long Revolution (London: Penguin).

Young, J. (1988) Writing and Rewriting the Holocaust (Bloomington: Indiana University Press).

Young, J. (1993) The Texture of Memory (New Haven: Yale University Press). 